
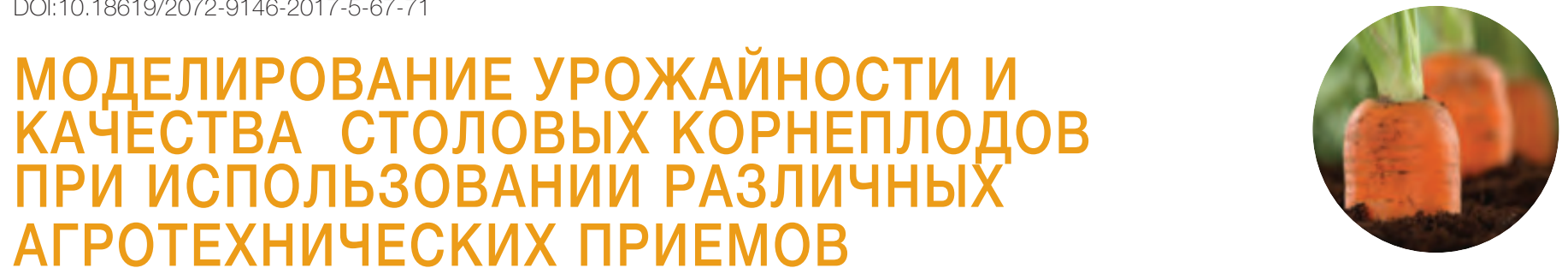

\title{
MODELING OF YIELD AND QUALITY OF TABLE ROOT CROPS WITH THE USE OF DIFFERENT AGROTECHNICAL METHODS
}

\author{
Надежкин C.M.1,3- доктор биол. наук, зам. директора \\ Гаплаев М.Ш. 2 - доктор с.-х. наук, директор \\ 1 ФГБНУ «Федеральный научный центр овощеводства» (ФГБНУ ФНЦО) \\ 143080, Россия, Московская обл. \\ Одинцовский р-н, пос. ВНИИССОК, ул. Селекционная, 14 \\ E-mail: nadegs@yandex.ru \\ 2 ФГБНУ «Чеченский НИИСХ» \\ 366021, Россия, Чеченская Республика, \\ Грозненский р-н, п. Гикало, ул. Ленина, 1 \\ E-mail: chechniish@mail.ru \\ з Учебно-опытный почвенно-экологический центр \\ МГУ имени М.В. Ломоносова \\ 141592, Россия, Московская область, \\ Солнечногорский район, п/о Ударный, пос. Чашниково
}

В условиях полевых опытов, проведенных в предгорной зоне Чеченской республики, изучали влияние различных доз удобрений, орошения и нормы высева моркови и свеклы столовой. Использование $N_{40-80} P_{40-80} K_{40-80}$ при возделывании моркови столовой обеспечивает рост урожайности с 22,8 до 30,8-33,2 т/га, или на 35-46\%. Под влиянием орошения урожайность возрастает на 30-33\%. Применение $N_{40} P_{40} K_{40}$ и поддержание влажности почвы на уровне 70\% НВ при выращивании моркови обеспечивает улучшение товарно-хозяйственных и биохимических показателей корнеплодов, что проявляется в увеличении содержания сухого вещества, суммы сахаров и витаминов. Математический моделирование процессов формирования урожайности и качества корнеплодов моркови и свеклы столовой показывает, что для формирования максимальной продуктивности в условиях черноземных почв предгорной зоны Центрального Предкавказья оптимальный уровень минерального питания должен быть на уровне


печивает прироста урожайности и приводит к снижению качества продукции. Повышение уровня предполивной влажности свыше 70-75\% НВ также не обеспечивает роста урожайности и вместе с тем снижает качество корнеплодов. Использование математических моделей позволяет рационально определять нормы применения удобрений в зависимости от применения орошения и нормы высева при выращивании моркови и свеклы столовой.

Ключевые слова: морковь столовая, свекла столовая, минеральные удобрения, орошение, норма высева, урожайность, моделирование, биохимический состав.

Для цитирования: Надежкин С.М., Гаплаев М.Ш. Моделирование урожайности и качества столовых корнеплодов при использовании различных агротехнических приемов. Овощи России. 2017;(5):67-71. DOI:10.18619/2072-9146-2017-5-67-71
Nadezhkin S.M. 1,3, Doctor of Sciences, Deputy Director

Gaplaev M.Sh.2, Doctor of Sciences, Director



The effects of different fertilizer rates, irrigation, sowing rate for carrot and red beet were studied in the field condition in food-hills zone of Chechen Republic. The use of $\mathrm{N}_{40-80} P_{40}$ ${ }_{80} K_{40-80}$ caused the increase in yield from 22.8 to $30.8-33.2$ t/ha or by $35-46 \%$, when cultivating a carrot crop. Under irrigation the yield increases by 30-33\%. Application of $\mathrm{N}_{40} P_{40} K_{40}$ and maintenance of soil moisture at $70 \%$ of moisture rate provoked the improvement in value, market and biochemical characteristics of roots; where the increased contents of dry matter, total sugar and vitamins were observed. The mathematical modeling for the process of yielding abilities and root quality in carrot and red beet showed that highest productivity can be achieved on chernozem soil at Central Pre-Caucasus zone when the level of mineral plant nutrition was $N_{40-60} P_{40-60} K_{40-60}$. The further increment in fertilizer doses does not bring an improvement to yields and leads to decrease in quality of yields. The increased level of antecedent soil water moisture $70-75 \%$ of moisture rates does not raise the yield, on the contrary decreasing at the same time the root quality. The use of mathematical modeling enables to rationally define the fertilizer rates depending on application of irrigation and sowing rates in cultivation of carrot and red beet.

Keywords: garden carrot, red beet, mineral fertilizers, irrigation, sowing rates, yielding, modeling, biochemical composition.

For citation: Nadezhkin S.M., Gaplaev M.Sh. Modeling of yield and quality of table root crops with the use of different agrotechnical methods. Vegetable crops of Russia. 2017;(5):67-71. (In Russ.) DOI:10.18619/2072 9146-2017-5-67-71
Введение

М атематическое моделирование ных культур предполагает поиск оптимального уровня и соотношения факторов, влияющих на него [10]. Математическая модель в конкретном случае строится на основании формализованных в виде уравнений регрессии производственных функций, которые выражают количественную связь урожая с факторами производства (агроклиматические и почвенные ресурсы, физиологи- ческие процессы в растении и т.д.). Производственные функции предназначены для установления пределов возможного увеличения урожайности сельскохозяйственных культур при оптимизации данных факторов или минимизации затрат ресурсов на получение заданного урожая [14].

На современном этапе нужно решать задачи моделирования на уровне выявления регрессионных связей с определением параметров действующих факторов в условиях конкретных климатических условий для выявления лимитирующих среди них и поиска технологических приемов, обеспечивающих ослабление их отрицательного действия [5, 11].

При решении задач по повышению эффективности использования земельных ресурсов и получению высоких и устойчивых урожаев сельскохозяйственных культур наибольший интерес представляют рост и развитие сельскохозяйственных растений (продукционный процесс) на конкретном поле. Соответствующие технологии информа- 
ционного обеспечения процесса принятия решений требуют оценки качества и количества растениеводческой продукции, что невозможно без применения метода моделирования, а использование при этом динамических имитационных моделей агроэкосистем является перспективным направлением. Однако несоответствие моделей процессам и явлениям, реально имеющим место на полях, приводит $\mathrm{K}$ потере всех преимуществ управления с использованием современных информационных технологий, нерациональному использованию ресурсов и развитию экологически неблагоприятных процессов [1, 10].

Сложность и нелинейность зависимостей между признаками часто делает применение классических методов прикладной статистики для построения моделей урожайности малоэффективным, а результаты моделирования трудно интерпретируемыми [7]. Кроме этого, сельхозпредприятия не всегда содержат в своем штате аналитиков, имеющих соответствующую математическую подготовку. В этой связи практический интерес представляет разработка методик применения различных эвристических методов, которые, хотя и не являются полностью математически обоснованными, позволяют получить приемлемое решение в большинстве практически значимых случаев [4].

В этой связи целью нашей работь было выявление оптимальных параметров использования удобрений и орошения при разных нормах высева путем поиска математических зависимостей формирования урожайности и качества корнеплодов моркови и свеклы столовой.

Условия и методика

проведения исследований

Исследования проводились в ГУП Госхоз «Орджоникидзевский» АчхойМартановского района, расположенном в предгорной зоне Чеченской республики. Агрохимическая характеристика пахотного (0-30 см) чернозема обыкновенного имела следующие показатели: нейтральная реакция среды - pHkcl 6,9-7,0, содержание гумуса по Тюрину - 4,1-4,2\%, щелочногидролизуемого азота по
Корнфильду - 85-115 мг/Кг почвы, подвижного фосфрора по Труогу - 32-45 мг, обменного калия по Бровкиной - 310-380 МГ/КГ почвы.

Схема опыта: (3×3×3)×3 со следующими факторами и градациями:

Фактор А - применение удобрений: 1 без внесения удобрений, 2 - одинарная доза минеральных удобрений $\left(\mathrm{N}_{40} \mathrm{P}_{40} \mathrm{~K}_{40}\right)$, 3 - двойная доза ( $\left.\mathrm{N}_{80} \mathrm{P}_{80} \mathrm{~K}_{80}\right)$.

Фактор В - предполивная влажность почвы: 1 - полив при влажности ниже $60 \%$ НВ, 2 - ниже 70\%, 3 - полив при влажности ниже 80\% НВ.

Фактор C - норма высева: моркови столовой 1 - 444 тыс. шт/га, 2 - 770, 3 855 тыс. /га; свеклы столовой соответственно 278, 463 и 537 тыс.шт/га. $25 \mathrm{M}^{2}$

Учетная площадь опытных делянок -

\section{Результаты и их обсуждение}

Применение удобрений, создание хорошей влагообеспеченности во все периоды вегетации, использование оптимальных сроков посева и густоты стояния растений в соответствии с генетическими потребностями конкретной культуры, сорта или гибрида - основа получения максимального урожая [8, 9, 13]

В среднем за годы исследований влияние изучаемых факторов на урожайность моркови определялось как их действием, так и взаимодействием. Под влиянием одинарной нормы применения удобрений, в среднем по остальным факторам, урожайность корнеплодов возрастала с 22,8 до 30,8-33,2 т/га, или на 35-46\% (табл. 1).

Вместе с тем, действие удобрений определялось и другими факторами. Так, при низкой влажности почвы высокие дозы удобрений $\left(\mathrm{N}_{80} \mathrm{P}_{80} \mathrm{~K}_{80}\right)$ не обеспечивали повышения продуктивности моркови, или даже вызывали тенденцию ее снижения, так как при этом возрастает концентрация почвенного раствора, отрицательно действующая на деятельность корневой системы овощных культур [15]. При поддержании предполивной влажности почвы на уровне 70-80\% НВ использование удобрений, как в одинарной, так и двойной норме приводило к статистически доказуемому росту урожайности корнеплодов. При этом, если рост урожайно- сти от использования $\mathrm{N}_{40} \mathrm{P}_{40} \mathrm{~K}_{40}$, составил 8,0 т/га, то применение $\mathrm{N}_{80} \mathrm{P}_{80} \mathrm{~K}_{80}$ в сравнении с предыдущей нормой обеспечило получение дополнительно только 2,4 т/га корнеплодов, или в расчете на килограмм действующего вещества удобрений, в 3,4 ниже.

При выращивании моркови на Северном Кавказе увеличение доз удобрений свыше N90P90K90 не повышает урожайность и является излишним [12].

В зависимости от густоты стояния растений эффективность применения удобрений также различалась, но зависела от использования орошения. При этом рост нормы удобрений с $\mathrm{N}_{40} \mathrm{P}_{40} \mathrm{~K}_{40}$ до $\mathrm{N}_{80} \mathrm{P}_{80} \mathrm{~K}_{80}$ при увеличении нормы высева с 444 до 855 тыс.шт./га без использования поливов обеспечивал рост урожайности на 0,8-1, т/га, а при поддержании влажности на уровне 70-80\% HB - на 4,34,4 и 2,0-2,9 т/га соответственно.

Регулирование водного режима почвы также оказывало существенное влияние на урожайность корнеплодов. В среднем по остальным факторам, использование орошения обеспечивало увеличение урожайности моркови с 24,1 до 30,0-32,6 т/га, или на 24-35\%. При этом эффективность использования поливной воды определялась, в первую очередь, использованием удобрений. Так, без применения удобрений рост уровня предполивной влажности с 70 до 80\%НВ ни при одной густоте стояния растений не обеспечивал достоверного увеличения урожайности, а при использовании обеих норм удобрения способствовал статистически доказуемому росту урожайности.

Статистическая обработка экспериментального материала при изучении различных типов гибридов, проведенная на основании исследований ВНИИО, показала, что связь между густотой стояния и массой корнеплода моркови прямая, отрицательная с коэффициентом корреляции от -0,896 до -0,940 [6].

Густота стояния растений из изучаемых факторов оказывала наименьшее влияние на урожайность корнеплодов, но это зависело от сочетания других агроприемов. В целом по опыту, рост нормы высева с 444 до 770-855 тыс./га, обес-

Таблица 1. Урожайность моркови гибрида $F_{1}$ Грибовчанин в зависимости от удобрения,

орошения и нормы высева, т/га, среднее за 2004-2006 г.оды

\begin{tabular}{|c|c|c|c|c|c|c|}
\hline \multirow{2}{*}{$\begin{array}{c}\text { Дозы } \\
\text { удобрений, } \\
\text { кг/га, д.в. } \\
\text { (фактор А) }\end{array}$} & \multirow{2}{*}{$\begin{array}{c}\text { Норма } \\
\text { высева, } \\
\text { тыс. шт./га } \\
\text { (фактор В) }\end{array}$} & \multicolumn{3}{|c|}{$\begin{array}{c}\text { Влажность } \\
\text { почвы. \% НB (фактор С) }\end{array}$} & \multirow{2}{*}{$\begin{array}{c}\text { Средняя } \\
\text { по А, } \\
\frac{\text { т/га }}{\%}\end{array}$} & \multirow{2}{*}{$\begin{array}{c}\text { Средняя } \\
\text { по В, } \\
\frac{\text { т/га }}{\%}\end{array}$} \\
\hline & & 60 & 70 & 80 & & \\
\hline \multirow{3}{*}{$\begin{array}{l}\text { Без } \\
\text { удобрения }\end{array}$} & 444 & 19,0 & 22,2 & 23,1 & \multirow{3}{*}{$\frac{22,8}{100,0}$} & $27,2 / 100,0$ \\
\hline & 770 & 21,7 & 23,4 & 24,0 & & $29,3 / 107,7$ \\
\hline & 855 & 22,0 & 24,6 & 25,0 & & $30,2 / 111,0$ \\
\hline \multirow[t]{3}{*}{$\mathrm{N}_{40} \mathrm{P}_{40} \mathrm{~K}_{40}$} & 444 & 23,6 & 29,4 & 33,6 & \multirow{3}{*}{$\frac{30,8}{135,1}$} & \\
\hline & 770 & 26,2 & 31,4 & 36,7 & & \\
\hline & 855 & 26,4 & 32,3 & 37,2 & & \\
\hline \multirow[t]{3}{*}{$\mathrm{N}_{80} \mathrm{P}_{80} \mathrm{~K}_{80}$} & 444 & 24,4 & 33,7 & 35,6 & \multirow{3}{*}{$\frac{33,2}{145,6}$} & \\
\hline & 770 & 26,3 & 36,5 & 37,7 & & \\
\hline & 855 & 27,5 & 36,7 & 40,1 & & \\
\hline \multirow[t]{2}{*}{ Средняя по С, т/га } & & 24,1 & 30,0 & 32,6 & & \\
\hline & & 100,0 & 124,5 & 135,3 & & \\
\hline
\end{tabular}

HCP $_{05}: A=B=C=1,6, H_{05}$ частных различий $-2,8$ 
Таблица 2. Доля влияния факторов на формирование урожайности моркови и свеклы столовой

Факторы

Морковь столовая товарная урожайность
Свекла столовая

общая урожайность

товарная урожайность

\begin{tabular}{|l|l|}
\hline 43,1 & 15,5 \\
\hline 24,8 & 29,7 \\
\hline 11,3 & 30,3 \\
\hline 3,1 & 2,8 \\
\hline 2,6 & 4,1 \\
\hline 2,7 & 3,9 \\
\hline 0,4 & 3,5 \\
\hline 11,8 & 10,2 \\
\hline
\end{tabular}

Удобрения A

38,1

40,1

25,2

18,6

Норма высева C

30,2

12,4

Взаимодействие АС

Взаимодействие ВС

Взаимодействие АВС

Неучтенные факторы (погода)

печивал рост урожайности с 27,2 до 29,330,2 т/га, или на 8-11\%. Вместе с тем, без применения удобрений использование максимальной густоты стояния растений обеспечивало статистически доказуемый рост урожайности только при сочетании N80P80К80 и предполивной влажности 80\%НВ. В связи с тем, что при увеличении нормы высева растений моркови гибрида F1 Грибовчанин свыше 770 тыс.шт./га достоверного роста урожайности не происходит, можно сделать предположение о том, что нет необходимости в более высокой загущенности растений при выращивании сортотипа Нантская.

Статистическая обработка экспериментальных данных показала, что в формировании как общей, так и товарной урожайности моркови столовой определяющую роль играют два основных фактора - применение удобрений и орошение. На их долю приходилось соответственно 38,1-30,2 и 25,2-40,1\% общего варьирования урожайности корнеплодов (табл. 2). Густота стояния растений оказывала значительно меньшее влияние 12,4-12,8\%. На долю погодных условий приходилось всего 6,7-9,3\%, а на взаимодействие изучаемых факторов - 9,410,0\% изменчивости [2, 3].
3,5

1,4

\begin{tabular}{|l|l|}
\hline 4,3 & 3,5 \\
\hline 1,2 & 1,4 \\
\hline 1,9 & 2,3 \\
\hline 2,6 & 2,2 \\
\hline 9,3 & 6,7 \\
\hline
\end{tabular}

Статистическая обработка экспериментального материала позволила выявить, что между изучаемыми факторами с одной стороны и урожайностью корнеплодов, их товарными и хозяйственными качествами, а также биохимическим составом, с другой, существуют определенные зависимости. Использование полной факториальной схемы проведения экспериментальных исследований дало возможность математически описать процессы формирования урожайности и качества корнеплодов моркови (табл. 3), а их графическое отображение - дать возможность количественно определить изменения в изучаемом показателе в зависимости от величины опытного фактора (доз удобрений, уровня влажности, густоты стояния растений).

Так, при изучении взаимодействия применения удобрений и орошения на урожайность моркови выявлено, что на неорошаемой почве использование $\mathrm{N}_{40} \mathrm{P}_{40} \mathrm{~K}_{40}$ вызывает рост урожайности на 2-4 т/га, а повышение дозы до N80P80K80 оказывает угнетающее влияние на данный показатель (рис. 1).

В то же время, при поддержании предполивной влажности на уровне 70\% НВ, прибавка урожайности от использования умеренных и повышенных доз минеральных удобрений достигает 8-12 т/га, а при 80\% НВ - 16-20 т/га. Использование орошения без использования удобрений вызывает рост урожайности на 2-4 т/га, а при внесении $\mathrm{N}_{40-80} \mathrm{P}_{40-80} \mathrm{~K}_{40-80}$ прирост продуктивности достигает 6-14 т/га.

Изучение взаимосвязи влияния удобрений и густоты состояния растений показало, что без использования удобрений рост нормы высева со 444 до 855 тыс. шт/га не оказывает влияния на урожайность моркови (рис. 2). При использовании $\mathrm{N}_{40-80} \mathrm{P}_{40-80} \mathrm{~K}_{40-80}$ увеличение числа растений на единице площади обеспечивает рост урожайности на 3-8 т/га. Эффективность использования удобрений в определенной мере зависит от густоты стояния растений. Так, при высеве 444 тыс. шт/га от применения $\mathrm{N}_{40} \mathrm{P}_{40} \mathrm{~K}_{40}$ получено дополнительно 8 т/га корнеплодов, а при использовании повышенной нормы удобрений дальнейшего роста урожайности не происходит. В то же время при густотах 770 и 855 тыс./га применение $\mathrm{N}_{80} \mathrm{P}_{80} \mathrm{~K}_{80}$ дает дополнительную прибавку урожайности на уровне 3-5 т/га в сравнении с одинарной нормой удобрений.

Таблица 3. Фрагмент модели влияния изучаемых факторов на формирование урожайности и качества корнеплодов моркови столовой гибрида $F_{1}$ Грибовчанин

\section{Показатель (Z)}

\section{Уравнение регрессии}

$R^{2}$

Использование удобрений (х - единичная доза N, P и K), y - норма высева, тыс.шт/га

Товарность, \% $Z=51,17-0,011 x-0,00050 x^{2}+0,131 y-0,00011 y^{2}+0,000043 x y$

Масса корнеплода, г

$Z=40,97+0,506 x-0,00061 x^{2}+0,168 y-0,00015 y^{2}-0,00044 x y$

$z=5,96+0,023 x-0,00026 x^{2}+0,0015 y-0,000016 y^{2}+0,000026 x y$

Содержание сахаров, \%

$Z=8,60+0,043 x-0,00033 x^{2}+0,0019 y-0,000024 y^{2}+0,000032 x y$

Использование удобрений ( - единичная доза N, P и К), у - предполивная влажность почвы, \% НВ

Товарность, \%

$Z=51,17-0,011 x-0,00050 x^{2}+0,131 y-0,00011 y^{2}+0,000043 x y$

Масса корнеплода, г

$Z=-291,4-0,401 x-0,00061 x^{2}+10,08 y-0,067 y^{2}+0,0086 x y$

Содержание сахаров, \%

$Z=13,69+0,029 x-0,00026 x^{2}-0,190 y+0,0012 y^{2}-0,000062 x y$

Густота стояния растений, тыс. шт/га (х), у - предполивная влажность почвы, \% НВ

Урожайность, т/га

$Z=-80,59-0,0063 x+0,0000091 x^{2}+2,713 y-0,0165 y^{2}+0,000025 x y$

0,381

Товарность, \%

$Z=-163,75+0,114 x-0,00011 x^{2}+5,797 y-0,0387 y^{2}+0,00025 x y$

0,829

Масса корнеплода, г

$Z=-418,5+0,266 x-0,00015 x^{2}+11,56 y-0,067 y^{2}+0,0016 x y$

0,727

Содержание сахаров, \%

$Z=14,59+0,00059 x-0,0000016 x^{2}-0,203 y+0,0011 y^{2}+0,000014 x y$ 




Рис. 1. Влияние удобрений (x) и орошения (y) на урожайность (z) моркови, среднее за годы исследований

$Z=-71,2-0,110 x-0,0017 x^{2}+2,514 y$

$0,0165 y^{2}+0,0054 x y \quad R^{2}=0,930$

Анализ взаимосвязи содержания сухого вещества с применением удобрений и густотой стояния растений показывает, что применение двойной дозы туков с сравнении с одинарной при посеве 444 тыс. шт/га вызывает снижение содержания сухого вещества на 0,6-1,0\% (рис. 3). Однако при норме высева 770 и 855 тыс./га ингибирующего влияния повышенной нормы удобрений на данный показатель не выявлено. Следует отметить, что при загущении посевов без использования удобрений содержание сухого вещества снижается, а при использовании N40-80P40-80K40-80, наоборот количество его возрастает на 0,4-1,1\%.

Выявление взаимосвязи между урожайностью, товарность корнеплодов и их биохимическим составом, с одной стороны, и использованием удобрений, орошения и различной густотой стояния растений, с другой, можно использовать при выборе оптимально сочетания различных



Рис. 2. Влияние удобрений (x) и нормы высева (у) на урожайность (z) моркови, среднее за годы исследований

$Z=22,11+0,247 x-0,00174 x^{2}-0,0057 y+$

$0,000091 y^{2}+0,00031 x y \quad R^{2}=0,581$

агроприемов в зависимости от материально-технического состояния сельхозпроизводителей и их технической оснащенности в конкретных производственных условиях.

Статистическая обработка экспериментального материала и графическое отображение полученных уравнений регрессии (табл. 4, рис. 4-6) позволяют прогнозировать параметры формирования урожайности и качества корнеплодов свеклы столовой в условиях Центрального Предкавказья.

Сочетание удобрений и орошения определяет 83,7\% варьирования урожайности корнеплодов свеклы столовой (рис. 4). При этом максимальная урожайность получена при использовании $\mathrm{N}_{40-60} \mathrm{P}_{40-}$ ${ }_{60} \mathrm{~K}_{40-60}$ и уровне предполивной влажности 70-75\% НВ. Дальнейшее повышение, как доз удобрений, так и порога предполивной влажности не способствует росту урожайности корнеплодов. Аналогичный

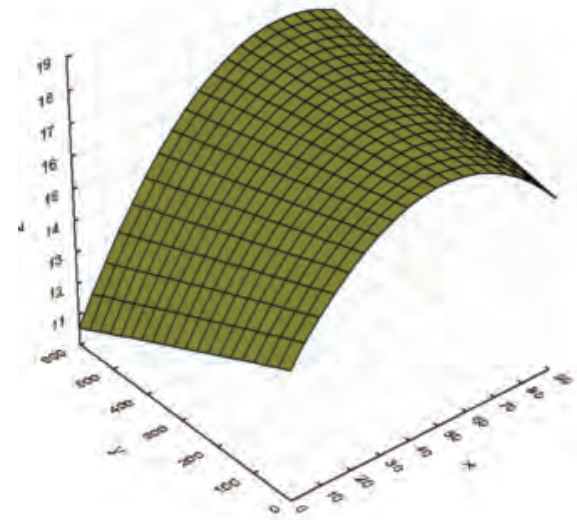

Рис. 3. Влияние удобрений $(x)$ и густоты стояния растений (у) на содержание сухого вещества в корнеплодах моркови (z), среднее за годы исследований

$Z=14,16+0,148 x-0,00016 x^{2}-0,0051 y-$ $0,000043 y^{2}+0,000036 x y \quad R^{2}=0,278$

характер взаимодействия этих факторов выявлен и для выхода товарной продукции и средней массы корнеплода.

Изучение взаимосвязи урожайности корнеплодов свеклы показывает, что применение повышенных норм высева без орошения вызывает тенденцию снижения урожайности на 0,8-1,2 т/га (рис. 5).

В то же время, предполивная влажность на уровне 70\% НВ обеспечивает существенный рост продуктивности культуры при использовании как низкой, так и повышенной нормы высева. При посеве 278 тыс./га поливы при уровне влажности почвы свыше 70\% НВ неэффективны, т.к. не обеспечивают получение дополнительного урожая, а увеличение нормы высева до 463-537 тыс./га способствует получению максимальной урожайности при поддержании предполивной влажности на уровне 75-80\% НВ.

Одностороннее увеличение, как коли-

Таблица 4. Фрагмент модели влияние изучаемых факторов на формирование урожайности и качества корнеплодов свеклы столовой сорта Бордо 237

\section{Показатель (Z) Уравнение регрессии}

Использование удобрений (х - единичная доза N, P и K), у - норма высева, тыс.шт/га

Урожайность, т/га

Товарность, \%

Содержание сахаров, \%

Содержание витамина С, мг\%

Содержание нитратов, мг/кг

$$
Z=24,24+0,315 x-0,0015 x^{2}+0,032 y-, 0056 x y
$$$$
Z=85,88+0,161 x-0,0019 x^{2}-0,028 y+0,00022 y^{2}-, 0027 x y
$$$$
Z=11,78+0,028 x-0,0016 x^{2}-0,0017 y+0,000020 y^{2}
$$$$
Z=14,06+0,136 x-0,0013 x^{2}-0,0057 y+0,00097 x y
$$$$
Z=595+6,8 x-0,051 x^{2}-0,23 y+0,0003 y^{2}+0,0006 x y
$$

Использование удобрений (х - единичная доза N, P и K), у - предполивная влажность почвы, \% НВ

Товарность, \%

$$
\begin{gathered}
Z=85,88+0,177 x-0,0022 x 2+0,108 y+0,00041 y^{2}+0,0021 x y \\
Z=11,18+0,023 x-0,000054 x^{2}-0,012 y-0,000090 y^{2} \\
Z=14,06+0,138 x-0,0014 x^{2}-0,034 y-0,000024 y^{2}+0,00059 x y \\
Z=558,9+7,38 x-0,059 x^{2}-0,031 y-0,0054 y^{2}+0,0096 x y
\end{gathered}
$$

Густота стояния растений, тыс. шт/га (х), у - предполивная влажность почвы, \% НВ

Товарность, \%

Содержание сахаров, \%

Содержание витамина С, мг\%

Содержание нитратов, мг/кг

$$
\begin{array}{|c|c|}
\hline Z=82,36+0,058 x-0,00011 x^{2}+0,014 y-0,00038 y^{2}+0,000077 x y & 0,729 \\
Z=10,09+0,010 x-0,000016 x^{2}+0,105 y-0,000037 y^{2} & 0,714 \\
\hline Z=11,44+0,028 x-0,000044 x^{2}+0,020 y-0,00023 y^{2} & 0,726
\end{array}
$$




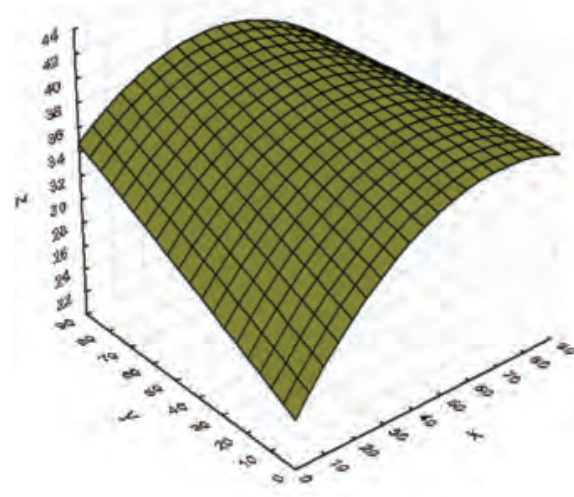

Рис. 4. Влияние удобрений $(x)$ и предполивной влажности почвы (y) на урожайность (z) корнеплодов свеклы столовой Бордо 237, среднее за 2008-2010 годы

$Z=24,24+0,363 x-0,0026 x^{2}+0,125 y+$ $0,00097 y^{2}-0,0015 x y \quad R^{2}=0,837$

чества удобрений, так и предполивной влажности, вызывает снижение содержания сухого вещества в корнеплодах свеклы столовой (рис. 6). Однако, при сочетании N80P80K80 и поддержания уровня влажности на уровне 75-80\% НВ накопление сухого вещества возрастает на 0,8$1,4 \%$

\section{Заключение}

Таким образом, статистический анализ взаимосвязи формирования урожайности и качества корнеплодов моркови и свеклы столовой с изучаемыми



Рис. 5. Влияние нормы высева $(x)$ и предполивной влажности почвы (у) на урожайность (z) корнеплодов свеклы столовой Бордо 237, среднее за 2008-2010 годы

$Z=9,054+0,110 x-0,00015 x^{2}+0,133 y-$ $0,0019 y^{2}+0,00030 x y \quad R^{2}=0,680$

агроприемами показывает, что между ними существуют адекватные зависимости, описываемые уравнении регрессии второго порядка. Ддля формирования максимальной продуктивности в условиях черноземных почв предгорной зоны Центрального Предкавказья оптимальный уровень минерального питания должен быть на уровне N40-60P4060K40-60. Дальнейший рост доз удобрений не обеспечивает прироста урожайности и приводит к снижению качества продукции, что проявляется в снижении содержания в корнеплодах сухо-

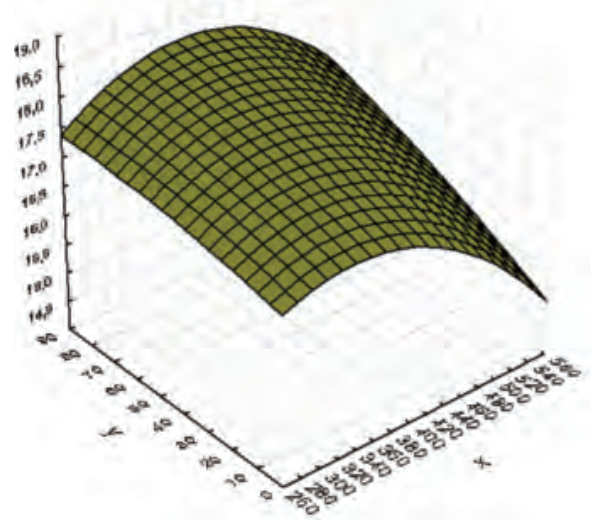

Рис. 6. Влияние удобрений $(x)$ и предполивной влажности почвы (у) на содержание сухого вещества (z) в корнеплодах свеклы столовой Бордо 237, среднее за 2008-2010 годы $Z=15,83+0,082 x-0,00091 x^{2}-0,033 y-$ $0,00056 x y$

$R^{2}=0,728$

го вещества, сахаров и витамина C и росте накопления нитратов. Повышение уровня предполивной влажности свыше $70-75 \%$ НВ также не обеспечивает роста урожайности и вместе с тем, снижает качество корнеплодов. Использование полученных зависимостей позволит рационально определять нормы применения удобрений в зависимости от орошения и нормы высева растений при выращивании моркови и свеклы столовой.
- Литература

1. Арефьев Н.В., Баденко В.Л., Осипов Г.К. Оценка природно-ресурсного потенциа ла территории с испольлзованием ГИС-технологий // Региональная экология, 1998 - № 1.- C. 17-22.

2. Гаплаев. М.Ш., Пивоваров В.Ф., Надежкин С.М. Влияние удобрений и орошения на урожайность и качество корнеплодов свеклы столовой / // Овощи России, 2014 - №1 (22). - C. 80-85.

3. Гаплаев, М.Ш., Цаболов П.Х. Морковь столовая в Центральном Предкавзье. Грозный.: ФГУП «ИПК Грозненский рабочий». 2011. - 208 с.

4. Евстропов А.С., Артамонов В.А. Системы управления производством сельскохозяйственной продукции на основе информационно-инновационных технологий. Рязань: ГНУ ВНИИМС, 2009. - 196 с.

5. Крючков А.Г. Основы математического моделирования на сельскохозяйственно поле. - Оренбург, 2012. - 162 с.

6. Леунов В.И., Рыбалко А.А., Михеев Ю.Г. Селекция и семеноводство моркови столовой / Научный редактор - С.С. Литвинов. - М., ВНИИО. - 2006. - 233 с.

7. Надежкин С.М. Изучение взаимосвязи органического вещества с продуктивностью культур и моделирование гумусного состояния почв лесостепи Среднего Поволжья // В сборнике: Методы исследований органического вещества почв. Редакторы: Еськов А.И., Черников В.А., Лукин С.М., Русакова И.В.. Владимир, 2005. C. 29-43.

8. Назарюк, В.М. Эколого-агрохимические и генетические проблемы регулируемых агроэкосистем / В.М. Назарюк. - Новосибирск: Изд-во СО РАН, 2004. - 240 с.

9. Оценка оптимального уровня интенсивности химизации при возделывании овощных культур. / Надежкин С.М., Терешонок В.И., Добруцкая Е.Г. и др. [Под общ. ред. С.М. Надежкина]. - М.: ВНИИССОК, 2012. - 44 с

10. Полуэктов Р.А., Смоляр Э.И., Терлеев В.В., Топаж А.Г... Модели продукционного процесса сельскохозяйственных растений / - СПб.: Изд-во СанктПетербургского университета, 2006.- 395 с.

11. Росс, Ю.К. Математическое моделирование фотосинтетической про-дуктивности растений // Вестник АН СССР, 1972. - №12. - С. 99-106.

12. Столяров А.И. Минеральное питание и применение удобрений под овощные культуры и картофель в условиях Краснодарского края. Автореферат дисс. доктора с-х наук. Л. - 1974. - 41 с.

13. Сычев, В.Г., Шафран С.А.. Агрохимические свойства почв и эффективность минеральных удобрений - М.: ВНИИА, 2013. - 296 с.

14. Хаданович, Д.В. Математическое моделирование как инструмент программирования, прогнозирования и планирования урожайности сельскохозяйственных культур // Современные наукоемкие технологии, 2013. - № 8-1. - С. 84-85

15. Цаболов П.Х., Гаплаев М.Ш Столовые корнеплоды в Центральном Предкавказье. - Владикавказ: Изд-во ФГБОУ ВПО Горский ГАУ, 2014 - 224 с.

\section{- References}

1. Aref'ev N.V., Badenko V.L., Osipov G.K. Ocenka prirodno-resursnogo potenciala territorii s ispol'zovaniem GIS-tekhnologij // Regional'naya ehkologiya, 1998. - № 1.- S. 17-22

2. Gaplaev. M.SH., Pivovarov V.F., Nadezhkin S.M. Vliyanie udobrenij i orosheniya na urozhajnost' i kachestvo korneplodov svekly stolovoj / // Ovoshchi Rossii, 2014. №1 (22). - S. 80-85.

3. Gaplaev, M.SH., Cabolov P.H. Morkov' stolovaya v Central'nom Predkavz'e. Groznyj.: FGUP «IPK Groznenskij rabochij». 2011. - 208 s.

4. Evstropov A.S., Artamonov V.A. Sistemy upravleniya proizvodstvom sel'skohozyajstvennoj produkcii na osnove informacionno-innovacionnyh tekhnologij. - Ryazan': GNU VNIIMS, 2009. - $196 \mathrm{~s}$

5. Kryuchkov A.G. Osnovy matematicheskogo modelirovaniya na sel'skohozyajstvennom pole. - Orenburg, 2012. - $162 \mathrm{~s}$

6. Leunov V.I., Rybalko A.A., Miheev YU.G. Selekciya i semenovodstvo morkovi stolovoj / Nauchnyj redaktor - S.S. Litvinov. - M., VNIIO. - 2006. - 233 s.

7. Nadezhkin S.M. Izuchenie vzaimosvyazi organicheskogo veshchestva s produktivnost'yu kul'tur i modelirovanie gumusnogo sostoyaniya pochv lesostepi Srednego Povolzh'ya // V sbornike: Metody issledovanij organicheskogo veshchestva pochv. Redaktory: Es'kov A.I., CHernikov B.A., Lukin C.M., Rusakova I.V.. Vladimir, 2005. S $29-43$.

8. Nazaryuk, V.M. EHkologo-agrohimicheskie i geneticheskie problemy reguliruemyh agroehkosistem / V.M. Nazaryuk. - Novosibirsk: Izd-vo SO RAN, 2004. - $240 \mathrm{~s}$ 9. Ocenka optimal'nogo urovnya intensivnosti himizacii pri vozdelyvanii ovoshchnyh kul'tur. / Nadezhkin S.M., Tereshonok V.I., Dobruckaya E.G. i dr. [Pod obshch. red. S.M. Nadezhkina]. - M.: VNIISSOK, 2012. - $44 \mathrm{~s}$

10. Poluehktov R.A., Smolyar EH.I., Terleev V.V., Topazh A.G... Modeli produk cionnogo processa sel'skohozyajstvennyh rastenij / - SPb.: Izd-vo SanktPeterburgskogo universiteta, 2006.- 395 s.

11. Ross, YU.K. Matematicheskoe modelirovanie fotosinteticheskoj pro-duktivnosti rastenij // Vestnik AN SSSR, 1972. - №12. - S. 99-106.

12. Stolyarov A.I. Mineral'noe pitanie i primenenie udobrenij pod ovoshchnye kul'tury i kartofel' v usloviyah Krasnodarskogo kraya. Avtoreferat diss. doktora s-h nauk. L. - 1974.- $41 \mathrm{~s}$.

13. Sychev, V.G., SHafran S.A.. Agrohimicheskie svojstva pochv i ehffektivnost' mineral'nyh udobrenij - M.: VNIIA, 2013. - $296 \mathrm{~s}$.

14. Hadanovich, D.V. Matematicheskoe modelirovanie kak instrument programmirovaniya, prognozirovaniya i planirovaniya urozhajnosti sel'skohozyajstvennyh kul'tur // Sovremennye naukoemkie tekhnologii, 2013. - № 8-1. - S. 84-85.

15. Cabolov P.H., Gaplaev M.SH Stolovye korneplody v Central'nom Predkavkaz'e. Vladikavkaz: Izd-vo FGBOU VPO Gorskij GAU, 2014 - 224 s. 